\title{
Effect of ovarian hormones on oxytocin receptor concentrations in explants of uterus from ovariectomized ewes
}

\author{
E. L. Sheldrick and H. C. Flick-Smith \\ AFRC, Institute of Animal Physiology and Genetics Research, Babraham, Cambridge, CB2 4AT, UK
}

\begin{abstract}
The effects of oestradiol, progesterone, oxytocin and combinations of these hormones on oxytocin receptor binding in explants of uteri from ovariectomized ewes were determined. Receptor binding remained unchanged after $96 \mathrm{~h}$ in culture in control medium. Oestradiol at concentrations of 1 pmol-10 $\mathrm{moll}^{-1}$ did not alter receptor binding activity in tissue cultured for $96 \mathrm{~h}$, but at $100 \mu \mathrm{mol} \mathrm{l}^{-1}$ oestradiol significantly reduced $(P<0.01)$ receptor binding activity. Progesterone and oxytocin significantly reduced receptor binding activity in explants cultured for $96 \mathrm{~h}(P<0.05)$. Explants cultured in medium containing progesterone and oestradiol or oxytocin and oestradiol showed receptor binding characteristics similar to those found in tissue cultured with progesterone or oxytocin alone. When explants were cultured for $72 \mathrm{~h}$ in medium containing oestradiol followed by $24 \mathrm{~h}$ in medium containing oestradiol alone, oestradiol with oxytocin, oestradiol with progesterone, oxytocin alone, progesterone alone, or in medium with no added hormones, receptor binding activity was always reduced in the presence of progesterone and oxytocin whether or not oestradiol was present in the medium. Receptor binding activity in explants cultured for the final $24 \mathrm{~h}$ in medium containing oestradiol or no added hormones were similar to those in tissue cultured in control medium for a total of $96 \mathrm{~h}$. These data show that progesterone and oxytocin reduce oxytocin receptor binding activity in cultured uterine tissue and, in contrast to its effect on the rat uterus, that oestradiol is not a potent stimulator of oxytocin receptor synthesis in uterine tissue of ovariectomized ewes in vitro. These data also raise the possibility that post-receptor events resulting in increased secretion of prostaglandin $F_{2 \alpha^{\prime}}$ rather than oxytocin receptor synthesis, are controlled by oestrogen in sheep.
\end{abstract}

\section{Introduction}

Ovariectomized ewes have been used extensively to investigate events occurring during the ovine oestrous cycle (see Moore, 1988 for review). Administration of progesterone, or its analogues, alone or in combination with oestradiol, to ovariectomized ewes induces many of the events that occur in intact cyclic ewes, including the onset of behavioural oestrus (Robinson, 1955) and oxytocin-induced prostaglandin $\mathrm{F}_{2 \alpha}$ $\left(\mathrm{PGF}_{2 \alpha}\right.$ ) secretion (Vallet et al., 1990). Oxytocin-stimulated $\mathrm{PGF}_{2 \alpha}$ secretion depends on the presence of an active oxytocin receptor in the uterus (Sheldrick and Flint, 1984). Long-term ovariectomized ewes have concentrations of uterine oxytocin receptor that are significantly higher than those found in intact ewes during the mid-luteal phase of the oestrous cycle when the uterus is refractory to oxytocin (Sheldrick, 1990), and are more comparable to concentrations found after luteolysis has commenced on day 14 or 15 of the oestrous cycle (Sheldrick and Flint, 1985). However, oxytocin cannot stimulate $\mathrm{PGF}_{2 \alpha}$ secretion in ovariectomized ewes unless the receptor has been activated by administration of oestradiol (McCracken, 1980), progesterone (Vallet and Lamming, 1991) or a combination of

Received 2 March 1992. progesterone and oestradiol (Sheldrick and Flint, 1986). In the cyclic ewe, concentrations of oxytocin receptor are low during the mid-luteal phase of the oestrous cycle, but increase during luteolysis to reach maximum levels at oestrus (Roberts et al., 1976; Sheldrick and Flint, 1985). McCracken et al. (1984) suggested that synthesis of the uterine oxytocin receptor during luteolysis is controlled by progesterone and oestradiol: withdrawal of progesterone (Leavitt et al., 1985) and increased secretion of follicular oestrogen on the days leading up to ovulation stimulate receptor synthesis. McCracken (1980) showed that after $6 \mathrm{~h}$ exposure to oestradiol, given by means of continuous infusion, ovariectomized ewes secrete $\mathrm{PGF}_{2 \alpha}$ in response to oxytocin. This result has been interpreted as demonstrating an oestradiol-induced increase in oxytocin receptor formation, although concentrations of receptor in the uterus were not measured in these ewes. Sheldrick (1990) showed that steroid-treated ovariectomized ewes that released $\mathrm{PGF}_{2 \alpha}$ in response to oxytocin had endometrial oxytocin receptor binding activity similar to that in untreated ewes, but significantly higher concentrations of receptor activity were found in the myometrium of steroid-treated ewes than in untreated ewes. Myometrium has been shown to secrete very little PGF ${ }_{2 \alpha}$ in response to oxytocin (Roberts et al., 1976). As ovariectomized ewes that have not been exposed to steroid hormones do 
not respond to oxytocin by releasing $\mathrm{PGF}_{2 \alpha}$ (Sheldrick and Flint, 1986), it is possible that oestradiol induces a post-receptor event that results in increased secretion of $\mathrm{PGF}_{2 \alpha}$ rather than directly stimulating synthesis of the oxytocin receptor.

Another ovarian hormone, oxytocin, also appears to influence oxytocin receptor synthesis: when infused into ewes in the late-luteal phase of the oestrous cycle, oxytocin prevents the rise in oxytocin receptor concentrations usually associated with luteolysis and delays luteal regression by inhibiting pulsatile secretion of PGF $_{2 \alpha}$ (Sheldrick and Flint, 1990). The experiments described here were undertaken to investigate the effect of oestradiol, progesterone and oxytocin on oxytocin receptor binding activity in explants prepared from uteri of ovariectomized ewes that had not been treated with steroids.

\section{Materials and Methods}

\section{Animals}

Clun Forest ewes were ovariectomized at least three months before experimentation. Uteri were collected aseptically after administration of pentobarbitone sodium (Lethobarb: Duphar Veterinary Ltd, Southampton). All adhering membranes and extraneous tissues were removed from the uterine horns and these were then prepared for culture by cutting them into small pieces with scissors and then chopping with a Mcllwain tissue chopper (Mickle Laboratory Engineering Ltd, Guildford). Because of the small amounts of tissue available from each ewe, no attempt was made to separate endometrium from myometrium in these experiments. Resulting explants were approximately $1 \mathrm{~mm}^{3}$. These were washed in and then suspended in Trowell T8 medium (Trowell, 1959) prepared in this laboratory containing 100 iu penicillin $\mathrm{ml}^{-1}, 100 \mu \mathrm{g}$ streptomycin $\mathrm{ml}^{-1}$. 2 mmol L-glutamine $\mathrm{I}^{-1}$ and fetal calf serum $(5 \% \mathrm{v} / \mathrm{v}$; all obtained from Gibco, Paisley). Explants were placed onto lens cleaning tissue (105, Whatman International Ltd, Maidstone) which was supported by stainless steel grids with approximately $100 \mathrm{mg}$ tissue on each grid and three grids per Petri dish $(60 \times 15 \mathrm{~mm}$, Falcon 1007, Becton Dickinson UK Ltd, Oxford). Sufficient medium was added to the dish $(9 \mathrm{ml})$ to ensure contact with the lens tissue, but not to submerge the explants. Culture was at $37^{\circ} \mathrm{C}$ in a humidified atmosphere of air $(95 \%)$ and $\mathrm{CO}_{2}(5 \%)$. Medium was changed at $24 \mathrm{~h}$ intervals. All cultures were performed in triplicate.

The viability of cultured tissue was tested by culturing explants from one ewe for $72 \mathrm{~h}$ in control medium or medium containing cycloheximide $\left(3.5 \mu \mathrm{moll}^{-1}\right)$ followed by $24 \mathrm{~h}$ in medium that contained $111.0 \mathrm{kBq} \mathrm{L}-\left[4,5-{ }^{3} \mathrm{H}\right]$ leucine (1.92 TBq $\mathrm{mmol}$; Amersham International plc, Amersham). After a further $24 \mathrm{~h}$, explants were harvested and membranes prepared as described below. Incorporation of $\left[{ }^{3} \mathrm{H}\right]$ leucine into membrane pellet and $100000 \mathrm{~g}$ supernatants was calculated.

\section{Oxytocin radioreceptor assay}

After $96 \mathrm{~h}$, explants were removed from the lens tissue, washed in 100 volumes of $\mathrm{NaCl}(0.9 \% \mathrm{w} / \mathrm{v})$ containing EDTA $\left(1 \mathrm{mmol} \mathrm{I}^{-1}\right)$. Some of the explants were removed at this stage, fixed in Bouin's solution and examined for tissue viability after staining with haematoxylin-eosin. Preparation of subcellular fraction and measurement of $\left[{ }^{3} \mathrm{H}\right]$ oxytocin binding were carried out as previously described by Sheldrick and Flint (1985). Briefly, receptor fractions $(50 \mu \mathrm{g}$ protein) were incubated at $25^{\circ} \mathrm{C}$ for $15 \mathrm{~min}$ in $0.1 \mathrm{ml}$ Tris- $\mathrm{HCl}\left(25 \mathrm{mmol} \mathrm{l}^{-1}\right.$; $\mathrm{pH} \mathrm{7.6)} \mathrm{con-}$ taining $0.1 \%(\mathrm{w} / \mathrm{v})$ bovine serum albumin, $\mathrm{MnCl}_{2}\left(1 \mathrm{mmol} \mathrm{l}^{-1}\right)$ and $\left[3,5{ }^{3} \mathrm{H}\right.$-Tyr]oxytocin $\left(5 \mathrm{nmol}^{-1} ; \quad 1224 \mathrm{GBq} \mathrm{mmol}^{-1}\right.$; NEN Research Products, Stevenage). Nonspecific binding was measured in the presence of $10 \mu \mathrm{mol}^{-1}$ unlabelled oxytocin. After incubation, tubes were transferred to an ice-bath and $2 \mathrm{ml}$ ice-cold Tris- $\mathrm{HCl}\left(25 \mathrm{mmoll}^{-1}\right.$; $\mathrm{pH} \mathrm{7.6)}$ containing bovine serum albumin $(0.1 \% \mathrm{w} / \mathrm{v})$ was added. Separation of free oxytocin from receptor-bound oxytocin was by filtration using Durapore membranes (GVWP, Millipore UK Ltd, Watford) in a sampling manifold (No. 1225; Millipore UK Ltd). This method of tissue preparation and assay for oxytocin receptor binding activity ensures dissociation of receptor-oxytocin complexes (Flint and Sheldrick, 1985).

\section{Protein assay}

Protein was measured by the method of Lowry et al. (1951). Volumes were reduced so that the assay could be used with 96-well microtitre plates (No. 611 F96, Sterilin, Hounslow), which were read at $720 \mathrm{~nm}$ (Argus 400 Microplate Reader, Canberra Packard, Pangbourne).

\section{Effect of oestradiol on oxytocin receptor concentrations}

Explants of uterus obtained from five ewes were cultured for $96 \mathrm{~h}$ in medium containing oestradiol (Sigma Chemical Company, Poole). Nine concentrations of hormone were used ranging from 1 pmol to $100 \mu \mathrm{moll}^{-1}$.

\section{Effect of oestradiol, progesterone and oxytocin on oxytocin receptor concentration}

Explants were cultured (triplicate dishes for each of five ewes) in medium containing oxytocin ( $1 \mathrm{nmol} \mathrm{I}^{-1}$; Bachem UK Ltd, Saffron Walden), progesterone $\left(100 \mathrm{nmol}^{-1}\right)$ or oestradiol $\left(100 \mathrm{nmol}^{-1}\right)$ or oestradiol $\left(100 \mathrm{nmol}^{-1}\right)$ with oxytocin $\left(1 \mathrm{nmoll}^{-1}\right)$ or oestradiol $\left(100 \mathrm{nmol}^{-1}\right)$ with progesterone $\left(100 \mathrm{nmoll}^{-1}\right)$. Concentrations of oxytocin receptor were measured after $96 \mathrm{~h}$ of culture.

\section{Effect of exposure of tissue to oestradiol for $72 \mathrm{~h}$ followed by progesterone or oxyfocin for $24 \mathrm{~h}$}

The effect of pre-incubating tissue with oestradiol $\left(100 \mathrm{nmoll}^{-1}\right)$ for $72 \mathrm{~h}$ followed by $24 \mathrm{~h}$ in medium containing oestradiol, a combination of oestradiol $\left(100 \mathrm{nmoll}^{-1}\right)$ and progesterone $\left(100 \mathrm{nmoll}^{-1}\right)$, or oestradiol $\left(100 \mathrm{nmoll}^{-1}\right)$ and oxytocin $\left(1 \mathrm{nmoll}^{-1}\right)$, or progesterone $\left(100 \mathrm{nmoll}^{-1}\right)$ or oxytocin $\left(\mathrm{Inmol} \mathrm{l^{-1 }}\right)$ or in the absence of hormones was investigated. Receptor binding activity was measured after culture. 


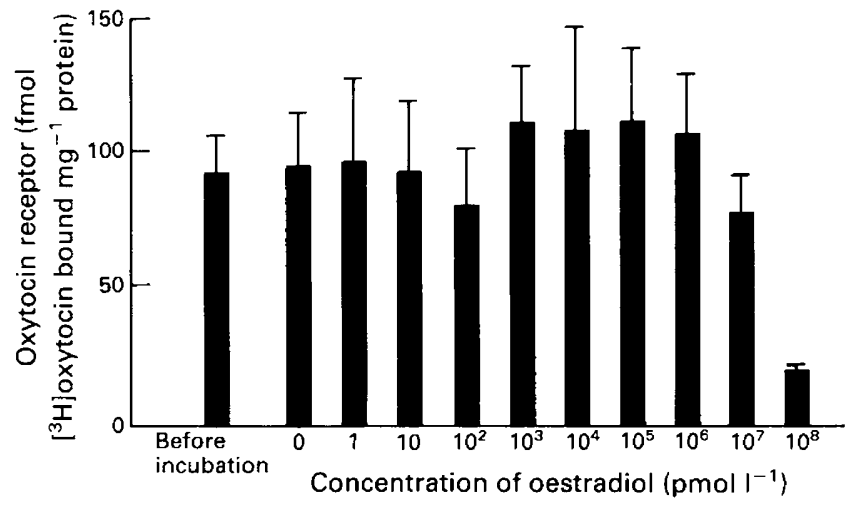

Fig. 1. Oxytocin receptor concentrations in uterine explants before incubation or after culture for $96 \mathrm{~h}$ in $(0)$ control medium or with different concentrations of oestradiol. Values are means \pm SEM for five ewes.

\section{Analysis of data}

Variances are expressed as SEM. Statistical differences were determined by Student's $t$ test.

\section{Results}

\section{Viability of the tissue}

Histological examination of cultured explants indicated that the tissue was viable $96 \mathrm{~h}$ after collection. No central necrosis or pycnotic nuclei were observed in explants exposed to any of the hormonal treatments described here. During the $72-96 \mathrm{~h}$ of culture $3.49 \pm 0.56 \mathrm{kBq}\left[{ }^{3} \mathrm{H}\right]$ leucine $\mathrm{mg}^{-1}$ protein was incorporated into the soluble fraction and $3.16 \pm 0.70 \mathrm{kBq} \mathrm{mg}^{-1}$ protein into the microsomal membrane fraction. In the presence of cycloheximide, these concentrations were reduced to $1.04 \pm 0.12 \mathrm{kBq} \mathrm{mg}^{-1}$ protein and $0.93 \pm 0.23 \mathrm{kBq} \mathrm{mg}^{-1}$ protein in soluble and membrane fractions, respectively $(P<0.05)$. These data indicate that protein was synthesized during the final $24 \mathrm{~h}$ of culture and that synthesis could be inhibited by cycloheximide.

\section{Effect of oestradiol on oxytocin receptor binding activity}

The concentration of oxytocin receptor in the tissue at the time of collection was $91.2 \pm 13.7 \mathrm{fmol}\left[{ }^{3} \mathrm{H}\right]$ oxytocin bound $\mathrm{mg}^{-1}$ protein ( $n=5$ ewes) (Fig. 1). The receptor binding activity in explants cultured for $96 \mathrm{~h}$ without hormones added to the medium was $94.9 \pm 20.0 \mathrm{fmol}\left[{ }^{3} \mathrm{H}\right]$ oxytocin bound $\mathrm{mg}^{-1}$ protein. Receptor concentrations in tissue cultured with oestradiol at concentrations of between 1 pmol and $10 \mu \mathrm{mol} \mathrm{l}^{-\mathrm{I}}$ were similar to those in tissue cultured in the absence of oestradiol. Oestradiol at $100 \mu \mathrm{mol} \mathrm{l}^{-1}$ significantly decreased receptor concentrations to $21.9 \pm 1.0 \mathrm{fmol} \mathrm{mg}^{-1}$ after $96 \mathrm{~h}$ in culture $(P<0.01)$.

Effect of oestradiol, progesterone and oxytocin on oxyfocin receptor concentrations

Progesterone and oxytocin significantly reduced the oxytocin binding activity in explants cultured for $96 \mathrm{~h}$ (Fig. 2). As in the

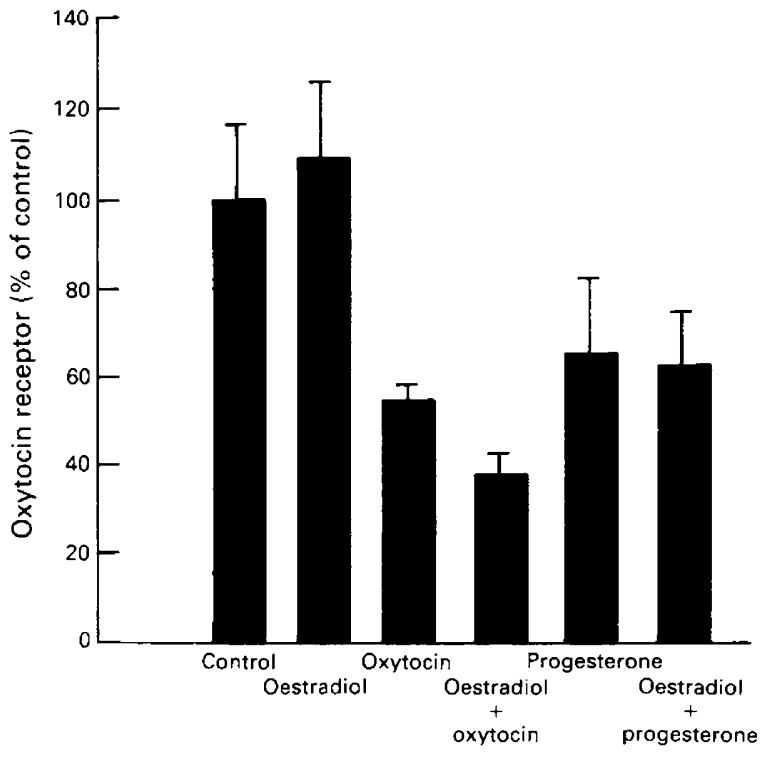

Fig. 2. Oxytocin receptor concentrations, expressed as $\%$ of $96 \mathrm{~h}$ control, in explants of ovariectomized sheep uterus cultured for $96 \mathrm{~h}$ with no added hormones; oestradiol (100 $\left.\mathrm{nmol} \mathrm{l}^{-1}\right)$; oxytocin $\left(1 \mathrm{nmol}{ }^{-1}\right)$; oestradiol $\left(100 \mathrm{nmol}^{-1}\right)$ plus oxytocin $\left(1 \mathrm{nmol}^{-1}\right)$; progesterone $\left(100 \mathrm{nmoll}^{-1}\right)$; oestradiol $\left(100 \mathrm{nmoll}^{-1}\right)+$ progesterone $\left(100 \mathrm{nmol} \mathrm{l}^{-1}\right)$. Values are means \pm SEM for five ewes.

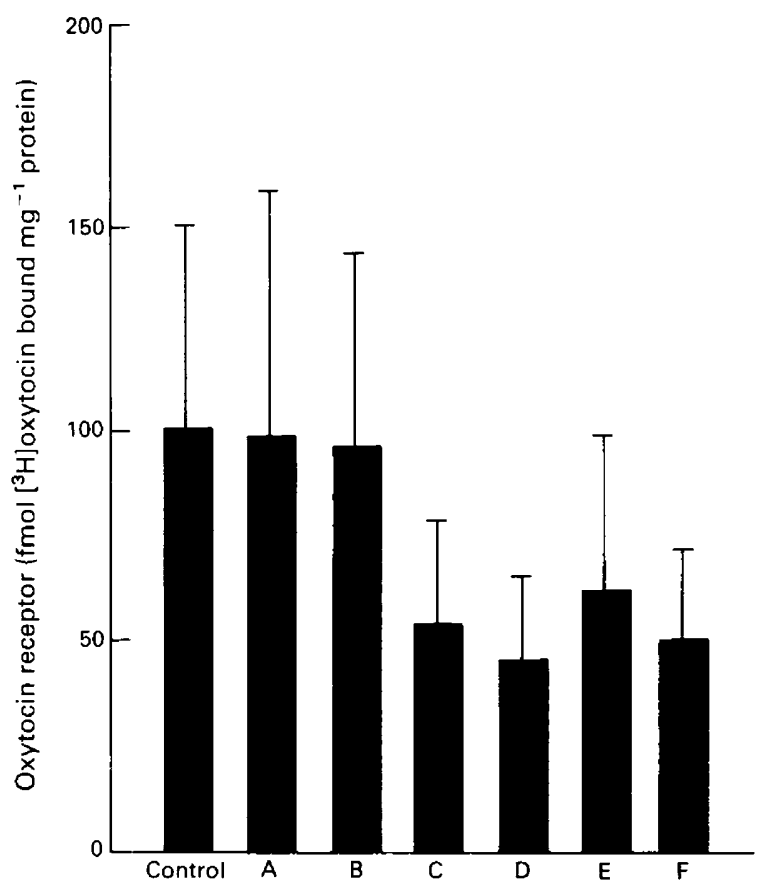

Fig. 3. Effect of culturing explants of uterus from ovariectomized sheep in control medium or in medium containing (A) oestradiol $\left(100 \mathrm{nmol} \mathrm{l}^{-1}\right)$ for $96 \mathrm{~h}$ or in medium containing oestradiol (100 nmol $\mathrm{l}^{-1}$ ) for $72 \mathrm{~h}$ followed by a further $24 \mathrm{~h}$ with (B) no added hormone, (C) oestradiol $\left(100 \mathrm{nmol}^{-1}\right)$ with progesterone $\left(100 \mathrm{nmoll}^{-1}\right)$, (D) oestradiol $\left(100 \mathrm{nmol} \mathrm{l}^{-1}\right)$ with oxytocin $\left(1 \mathrm{nmol} \mathrm{l}^{-1}\right)$, (E) progesterone $\left(100 \mathrm{nmol}^{-1}\right)$ or $(\mathrm{F})$ oxytocin $\left(1 \mathrm{nmoll}^{-1}\right)$. Values are means \pm SEM for tissue from five ewes. 
first experiment, oestrogen at a concentration of $100 \mathrm{nmol}^{-1}$ failed to affect receptor concentrations in the tissue. Receptor concentrations were reduced significantly in explants cultured with oestrogen and progesterone and in explants cultured with oestrogen and oxytocin $(P<0.05)$. Incubating explants with oestradiol for $72 \mathrm{~h}$ and then with oestradiol and progesterone, oestradiol and oxytocin, progesterone alone or oxytocin alone for $24 \mathrm{~h}$ resulted in a decrease in mean receptor concentration (Fig. 3) similar to that shown in Fig. 2. Explants cultured with oestradiol for $72 \mathrm{~h}$ followed by $24 \mathrm{~h}$ with oestradiol or no added hormones had a similar binding activity to that of explants cultured for $96 \mathrm{~h}$ in medium with no hormones added.

\section{Discussion}

Concentrations of uterine oxytocin receptor measured in the long-term ovariectomized ewes used in these experiments were similar to those reported previously (Sheldrick, 1990), but lower than those reported in corn-oil-treated anoestrous ewes ovariectomized 1 week (1802 $\mathrm{mol} \mathrm{mg}^{-1}$ protein; Vallet et al., 1990) or 6 weeks ( $300 \mathrm{fmol} \mathrm{mg}^{-1}$ protein; Zhang et al., 1992) before the measurement was made. As previously shown with rat uterus (Soloff et al., 1983), oxytocin receptor concentrations did not alter significantly when cultured in control medium (Fig. 1). This result indicates that any hormonal factors that may be present in the medium do not affect oxytocin receptor synthesis during culture. Oestradiol failed to stimulate oxytocin receptor synthesis in any of the experiments described here, but the highest concentration of oestradiol used $\left(100 \mu \mathrm{moll}^{-1}\right)$ caused a significant reduction in receptor concentration $(P<0.01)$. This may have been the result of toxicity of the steroid hormone at high concentrations or a pharmacological effect of oestradiol (Flint, 1970). These data differ from those of Soloff et al. (1983) who, using a similar technique with explants of uteri from 26-30-day-old rats, found that picomolar concentrations of oestradiol caused a fivefold increase in the amount of $\left.{ }^{3} \mathrm{H}\right]$ oxytocin bound $\mathrm{mg}^{-1}$ protein after 3 days in culture.

In the experiments described here, both progesterone and oxytocin reduced the oxytocin binding activity in cultured explants. During the mid-luteal phase of the oestrous cycle of the ewe, progesterone and oxytocin are secreted by the corpus luteum in maximal concentrations (Flint and Sheldrick, 1983). At this time, oxytocin receptor concentrations are low and there is evidence that continuous exposure of the uterus to oxytocin causes downregulation of the oxytocin receptor in cyclic ewes (Flint and Sheldrick, 1985). Treating ovariectomized ewes with progesterone for two or six days prevents oestradiol-induced uterine sensitivity to oxytocin. After 10 days of progesterone treatment, uterine responsiveness to oxytocin is restored (McCracken, 1980). Treating ovariectomized ewes with progesterone for ten or 30 days results in increased oxytocin receptor binding activity in the uterus and oxytocin-stimulated $\mathrm{PGF}_{2 \alpha}$ secretion occurs after ten, but not after 30 , days of treatment (Vallet and Lamming, 1991). Oestradiol has been shown to potentiate the effect of progesterone treatment on uterine sensitivity to oxytocin (Homanics and Silvia, 1988; Zhang et al., 1992). In the experiments described here, tissue exposed to progesterone for four days had a reduced amount of oxytocin binding activity. An inhibitory effect of short-term exposure to progesterone on oxytocin receptor synthesis has been reported to occur in vivo (Vallet et al., 1990). At a high concentration $\left(3.2 \mu \mathrm{moll}^{-1}\right)$, progesterone had no effect on receptor concentrations in rat uterus in vitro when used alone, but caused a significant decrease in oestradiol-stimulated receptor synthesis (Soloff et al., 1983).

The lack of effect of physiological concentrations of oestradiol on oxytocin receptor concentrations is difficult to explain. Koligian and Stormshak (1977), and Rexroad (1981) have demonstrated that there are oestradiol binding sites in endometrium and myometrium of ovariectomized ewes. One explanation is that oestradiol is metabolized by enzymes in fetal calf serum and its biological activity is lost. However, this is unlikely because the reduced level of binding activity in tissue cultured with the highest dose of oestradiol indicates that there is some oestrogen-mediated activity in the medium and, if oestradiol was stimulatory at lower doses, an effect should have been detected with at least one of the concentrations used. In addition, an effect of oestradiol on receptor concentration was detected in rat uterine explants using similar culture techniques, but with a higher concentration of fetal calf serum $(10 \%$; Soloff et al., 1983). It appears from the results of the experiments presented here that the effect of oestradiol on uterine oxytocin receptor synthesis in ewes is different from that in rats. Although the mature ovariectomized ewes used here are not directly comparable to immature rats used previously (Soloff et al., 1983), in vivo effects of oestrogen in ewes (Sharma and Fitzpatrick, 1974; Sheldrick and Flint, 1986) should be expected to occur in vitro. However, in the experiments reported here, none of the physiologically relevant effects of oestrogen, seen in cultured rat uterus (Soloff et al., 1983) was detected in cultured sheep uterus and the effect of progesterone differed from that in rats in that basal concentrations of receptors were reduced in ewes rather than oestradiol-induced receptors in rats. These data indicate that the mechanism controlling oxytocin receptor synthesis in sheep may be different from that in rats. Oxytocin decreased oxytocin receptor binding activity in ewes indicating that oxytocin acts directly on the uterus to regulate the oxytocin receptor. The effect of oxytocin on rat uterine oxytocin receptor synthesis in vitro has not been investigated.

In the experiments reported here, progesterone and oxytocin reduced receptor concentrations in cultured tissue and this result is consistent with the previously reported inhibitory action of these hormones (Flint and Sheldrick, 1985; Vallet et al., 1990). Oestradiol did not affect receptor concentration in these experiments, and it is possible that oestrogen acts to promote secretion of $\mathrm{PGF}_{2 \alpha}$ by the uterus rather than by stimulating synthesis of the oxytocin receptor.

\section{References}

Flint APF (1970) Effects of progesterone in vitro on glucose and acetate metabolism by the luteinized rat ovary Journal of Endocrinology 46 497-506 Flint APF and Sheldrick EL (1983) Evidence for a systemic role for ovarian oxytocin in luteal regression in sheep Journal of Reproduction and Fertility 67 215-225

Flint APF and Sheldrick EL (1985) Continuous infusion of oxytocin prevents induction of the uterine oxytocin receptor and blocks luteal regression in cyclic ewes Journal of Reproduction and Fertility 75 623-631 
Homanics GE and Silvia WJ (1988) Effects of progesterone and estradiol-17 $\beta$ on uterine secretion of prostaglandin $\mathrm{F}_{2 a}$ in response to oxytocin in ovariectomized ewes Biology of Reproduction 38 804-811

Koligian KB and Stormshak F (1977) Progesterone inhibition of estrogen receptor replenishment in ovine endometrium Biology of Reproduction 17 41.2-416

Leavitt WW, Okulicz WC, McCracken JA, Schramm W and Robidoux WF (1985) Rapid recovery of nuclear estrogen receptor and oxytocin receptor in the ovine uterus following progesterone withdrawal Journal of Steroid Biochemistry $22687-691$

Lowry OH, Rosebrough NJ, Farr AL and Randall RJ (1951) Protein measurement with the Folin phenol reagent Journal of Biological Chemistry 193 265-275

McCracken JA (1980) Hormone receptor control of prostaglandin $\mathrm{F}_{26}$ secretion by the ovine uterus Advances in Prostaglandin and Thromboxane Research $\mathbf{8}$ 1329-1344

McCracken JA, Schramm W and Okulicz WC (1984) Hormone receptor control of pulsatile secretion of $\mathrm{PGF}_{2 \alpha}$ from the ovine uterus during luteolysis and its abrogation in early pregnancy Animal Reproduction Science 7 31-55

Moore NW (1988) The ovariectomized ewe: its contribution to controlled breeding Australian Journal of Biological Sciences 41 15-22

Rexroad CE (1981) Estrogen and progesterone binding in the myometrium of the ewe II. Regulation by estradiol and progesterone Journal of Animal Science 53 1070-1076

Roberts JS, McCracken JA, Gavagan JE and Soloff MS (1976) Oxytocinstimulated release of prostaglandin $\mathrm{F}_{2 a}$ from ovine endometrium in vitro: Correlation with estrous cycle and oxytocin receptor binding Endocrinology 99 1107-1114

Robinson TJ (1955) Quantitative studies on the hormonal induction of oestrus in spayed ewes Journal of Endocrinology 12 163-173

Sharma SC and Fitzpatrick RJ (1974) Effect of oestradiol-17 $\beta$ and oxytocin treatment on PGF2 $\alpha$ release in the anoestrous ewe Prostaglandins 22 631-636
Sheldrick EL (1990) Effect of oestradiol-17 $\beta$ on uterine oxytocin receptor synthesis in vivo and in vitro Joumal of Reproduction and Fertility Abstract Series 5 Abstract 15

Sheldrick EL and Flint APF (1984) Ovarian oxytocin. In Gonadal Proteins and Peptides and their Biological Significance Ed. MR Sairam and LE Atkinson. World Scientific Publishing Company, Singapore

Sheldrick EL and Flint APF (1985) Endocrine control of uterine oxytocin receptors in the ewe Journal of Endocrinology 106 249-258

Sheldrick EL and Flint APF (1986) Transient uterine refractoriness after oxytocin administration in ewes Journal of Reproduction and Fertility 77 523-529

Sheldrick EL and Flint APF (1990) Effect of continuous infusion of oxytocin on prostaglandin $\mathrm{F}_{2 a}$ secretion and luteolysis in the cyclic ewe Reproduction, Fertility and Development 2 89-99

Soloff MS, Fernstrom MA, Periyasamy S, Soloff S, Baldwin S and Wieder M (1983) Regulation of oxytocin receptor concentration in rat uterine explants by estrogen and progesterone Canadian Joumal of Biochemistry and Cell Biology $61625-630$

Trowell OA (1959) The culture of mature organs in a synthetic medium Experimental Cell Research 16 118-147

Vallet JL and Lamming GE (1991) Ovine conceptus secretory proteins and bovine recombinant interferon $\alpha-1$ decrease endometrial oxytocin receptor concentrations in cyclic and progesterone-treated ovariectomized ewes Journal of Endocrinology $131475-482$

Vallet JL, Lamming GE and Batten M (1990) Control of endometrial oxytocin receptor and uterine response to oxytocin by progesterone and oestradiol in the ewe Journal of Reproduction and Fertility 90 625-634

Zhang J. Weston PJ and Hixon JE (1992) Role of progesterone and oestradiol in regulation of uterine oxytocin receptors in ewes Journal of Reproduction and Fertility 94 395-404 